\title{
Metode K-Means untuk Mengelompokkan Alumni Berdasarkan Waktu Mencari Pekerjaan
}

\author{
(K-Means Method for Grouping Alumni Based on Time of Finding a Job)
}

\author{
Ridho Muktiadi $^{1}$, Abid Yanuar Badharudin ${ }^{2}$ \\ ${ }^{1,2}$ Teknik Informatika, Fakultas Teknik dan Sains, Universitas Muhammadiyah \\ Purwokerto, Jalan Raya Dukuhwaluh PO.BOX 202 Purwokerto, Jawa Tengah 53182 \\ 1ridho.muktiadi@gmail.com \\ ${ }^{2}$ zaidsoft.indonesia@gmail.com
}

\begin{abstract}
ABSTRAK
Alumni Universitas Muhammadiyah Purwokerto (UMP) sampai dengan tahun 2018 mencapai 31.178 alumni. Melalui alumni perguruan tinggi dapat melakukan perbaikan dan penyesuian kurikulum sesuai dengan kebutuhan dunia kerja. Tracer study menjadi upaya UMP untuk memperoleh data alumni dari semua tahun lulusan yang sudah disajikan dalam bentuk sistem informasi tracer study (tracer.ump.ac.id). Hasil dari tracer study dikelompokan berdasarkan waktu mencari kerja dengan menggunakan metode KMeans. Terdapat 3 kelompok yaitu: Sangat Baik, kelompok 2 yaitu Baik, Cukup dan Kurang dan kelompok 3 : Sangat Kurang. Sistem dibuat menggunakan bahasa pemrograman PHP dan MySQL sebagai sarana penyimpanan data. Pengujian sistem dilakukan dengan menguji sistem secara fungsionalitas dan pengujian penerapan metode K-Means. Dari hasil pengujian sistem yang dilakukan menunjukkan sistem dapat mengelompokkan data tracer study sebanyak 2.716 ke dalam 3 kelompok yang sudah ditentukan.
\end{abstract}

Kata Kunci: K-Means, Waktu Mencari Kerja, Tracer Study, Alumni

\section{ABSTRACT}

Alumni of the Universitas Muhammadiyah Purwokerto (UMP) up to 2018 reached 31,178 alumni. Through college alumni can make improvements and adjust curriculum according to the needs of the workforce. Tracer study is an effort of the UMP to obtain alumni data from all graduate years which has been presented in the form of a tracer study information system (tracer.ump.ac.id). The results of the tracer study are grouped by the time they look for work using the K-Means method. There are 3 groups: Very Good, group 2: Good, Enough and Poor and group 3: Very Poor. The system is made using PHP and MySQL programming languages as a means of data storage. System testing is done by testing the system's functionality and testing the application of the $K$ Means method. From the results of system testing conducted shows the system can group 2,716 tracer study data into 3 predefined groups.

Keywords: K-Means, Time Seeking Work, Tracer Study, Alumni

\section{PENDAHULUAN}

Alumni adalah orang-orang yang telah mengikuti atau tamat dari suatu sekolah atau perguruan tinggi (Kemendikbud). Alumni Universitas Muhammadiyah Purwokerto (UMP) sampai dengan tahun 2018 mencapai 31.178 alumni. Tracer study menjadi upaya

(Metode K-Means untuk Mengelompokkan .......... Ridho Muktiadi, 
UMP untuk memperoleh data alumni dari semua tahun lulusan yang sudah disajikan dalam bentuk sistem informai tracer study (tracer.ump.ac.id). Waktu mencari pekerjaan menjadi sebuah informasi bagaimana alumni mampu bersaing dalam memperoleh pekerjaan, serta sebagai dasar UMP meningkatkan kualitas dari lulusan. Clustering adalah proses untuk mengorganisasikan sekelompok data kedalam kelompok-kelompok sedemikian rupa sehingga obyek-oyek yang serupa akan menjadi satu cluster sedangkan obyek-obyek yang tidak serupa menjadi anggota cluster yang lain. Dalam setiap cluster akan berisi data yang semirip mungkin. Ukuran kemiripan biasanya dihitung dengan jarak. Jarak dalam satu cluster dibuat sedekat mungkin jadi dalam satu cluster harus semirip mungkin dan dengan cluster yang lain harus berbeda (Muflikhah, 2018). Metode K-Means adalah metode yang termasuk dalam algoritma clustering berbasis jarak yang membagi data ke dalam sejumlah cluster dan algoritma ini hanya bekerja pada atribut numerik (Witten, 2012). K-means mempartisi objek yang ada kedalam satu atau lebih cluster atau kelompok berdasarkan karakteristiknya, sehingga objek akan dikelompokan berdasarkan karakteristik yang sama pada sebuah cluster dan objek yang mempunyai karakteristik yang berbeda dikelompokan kedalam cluster yang lain. Pengelompokkan data dengan karakteristik yang mirip pada setiap kelompok menggunakan metode ini diharapkan mampu mempermudah mengetahui keadaan data alumni berdasarkan waktu mencari pekerjaan sehingga bisa digunakan sebagai acuan peningkatan kualitas lulusan.

\section{METODE}

Data diperoleh dengan cara langsung memintakan data tersebut ke pihak pengelola sistem informasi tracer study di UMP. Sebelum mengelompokan data, terlebih dahulu perlu dibuat cluster sebagai wadah pengelompokan data tersebut. Mengacu pada Buku VI Matriks Penilaian Instrumen Akreditasi Program Studi Sarjana tahun 2008 (Badan Akreditasi Nasional Perguruan Tinggi, 2008 ) maka akan ada tiga cluster pada sistem ini; kelompok 1 : Sangat Baik (waktu tunggu $\leq 3$ bulan), kelompok 2 : Baik, Cukup dan Kurang ( 3 bulan < waktu tunggu < 18 bulan) dan kelompok 3 : Sangat Kurang (waktu tunggu $\geq 18$ bulan). Kemudian tentukan pusat cluster dengan menggunakan persamaan 1 (Prasetyo, 2012).

$$
C i=\frac{1}{M} \sum_{j=1}^{M} x_{j}
$$

Langkah selanjutnya, hitung jarak setiap data terhadap pusat cluster dengan mengunakan persamaan 2 .

$$
d=\sqrt{\left(x_{1}-x_{2}\right)^{2}+\left(y_{1}-y_{2}\right)^{2}}
$$

Kemudian kelompokan data ke dalam cluster dengan jarak terpendek menggunakan persamaan 3 .

$$
a_{i 1}=\left\{\begin{array}{cl}
1 & d=\min \left\{D\left(x_{i}, c_{1}\right)\right\} \\
0 & \text { lainnya }
\end{array}\right.
$$

Tahap terakhir, ulangi langkah 3, apabila masih ada data yang berpindah kelompok atau apabila ada perubahan nilai centroid.

(Metode K-Means untuk Mengelompokkan ........... Ridho Muktiadi, 


\section{HASIL DAN PEMBAHASAN}

Data yang digunakan adalah data alumni yang sudah mengisi tracer study, data diperoleh dari Alumni Center UMP. Alumni yang sudah mengisi tracer study berjumlah 2716 alumni. Jumlah cluster ditentukan berdasarkan Buku VI Matriks Penilaian Instrumen Akreditasi Program Studi Sarjana tahun 2008, maka akan ada tiga cluster pada sistem ini; kelompok 1 : Sangat Baik (waktu tunggu $\leq 3$ bulan), kelompok 2 : Baik, Cukup dan Kurang ( 3 bulan < waktu tunggu $<18$ bulan) dan kelompok 3 : Sangat Kurang (waktu tunggu $\geq 18$ bulan). Berdasarkan hal tersebut maka terdapat 3 cluster yang akan digunakan, yaitu: cluster Sangat Baik, cluster Baik, Cukup dan Kurang dan cluster Sangat Kurang. Sistem dibuat menggunakan bahasa pemrograman PHP dan database MySQL sebagai sarana penyimpanan data. Model Waterfall digunakan sebagai model pengembangan sistem pada penelitian ini Gambar 1.

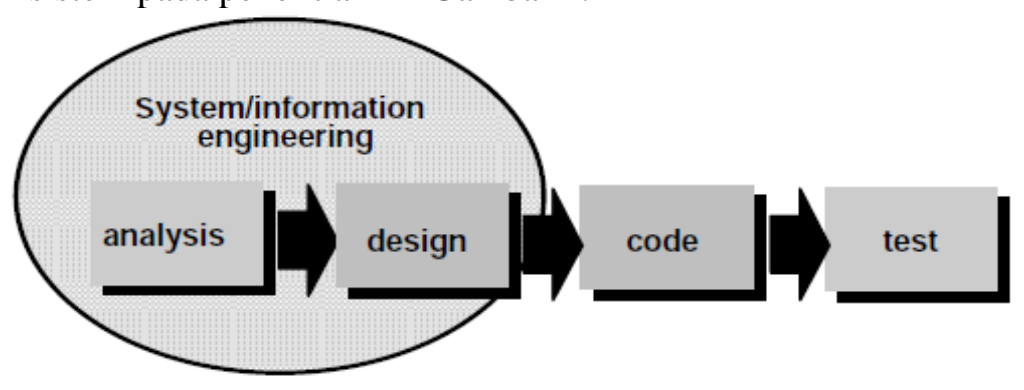

Gambar 1. Tahapan Model Waterfall (Pressman, 2002)

Sesuai dengan Gambar 1 maka akan ada 4 tahapan dalam pengembangan sistem yang harus dilakukan. Hasil dari pengembangan sistem yang telah dibuat, sebagai berikut:

\section{Analysis}

Tahap ini sudah terpenuhi berdasarkan tahap pengumpulan data, dimana data yang akan digunakan yaitu data alumni UMP yang sudah mengisi tracer study. Berdasrkan data tersebut dapat diketahui kebutuhan terkait data apa saja yang akan digunakan, kebutuhan tersebut meliputi: NIM, Nama Mahasiswa, Prodi, Fakultas, Tahun Lulus dan Jawaban pertanyaan waktu yang digunakan untuk mencari pekerjaan.

\section{Design}

Design yang dibuat meliputi: Use Case Diagram dan Activity Diagram.

a. Use Case Diagram

Use Case Diagram pada Gambar 2 menunjukan user dapat melakukan 2 proses utama yaitu melihat data alumni dan olah pengelompokan data. Proses lihat data alumni user dapat mengetahui jumlah data uyang akan diproses beserta isi data alumni dalam bentuk tabel. Pada proses pengelompokan data, user dapat mengetahui hasil dari pengelompokan data terhadap data alumni. 


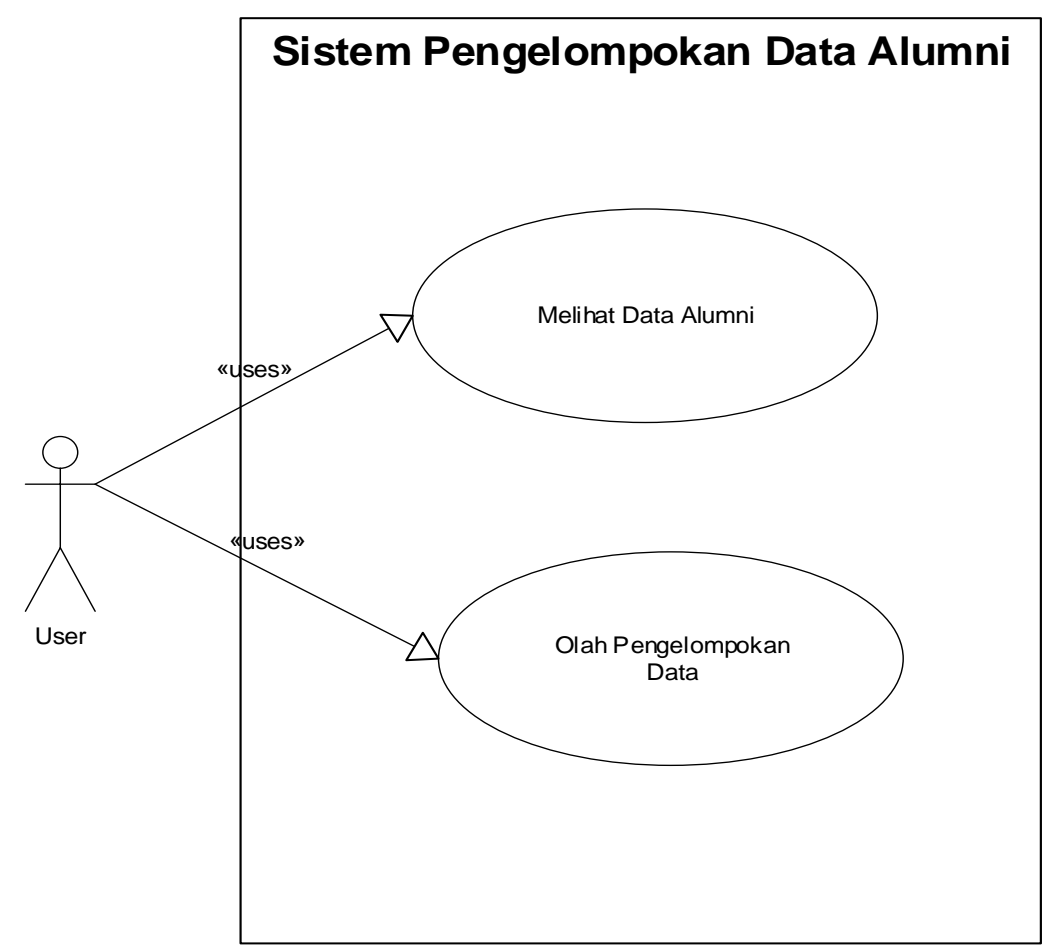

Gambar 2. Use Case Diagram Sistem Pengelompokan Data Alumni

b. Activity Diagram

Berdasarkan Use Case Diagram pada Gambar 2 terdapat 2 proses utama, sehingga pada tahap perancangan ini dibuat 2 activity diagram yang ditunjukkan pada Gambar 5 dan Gambar 3.

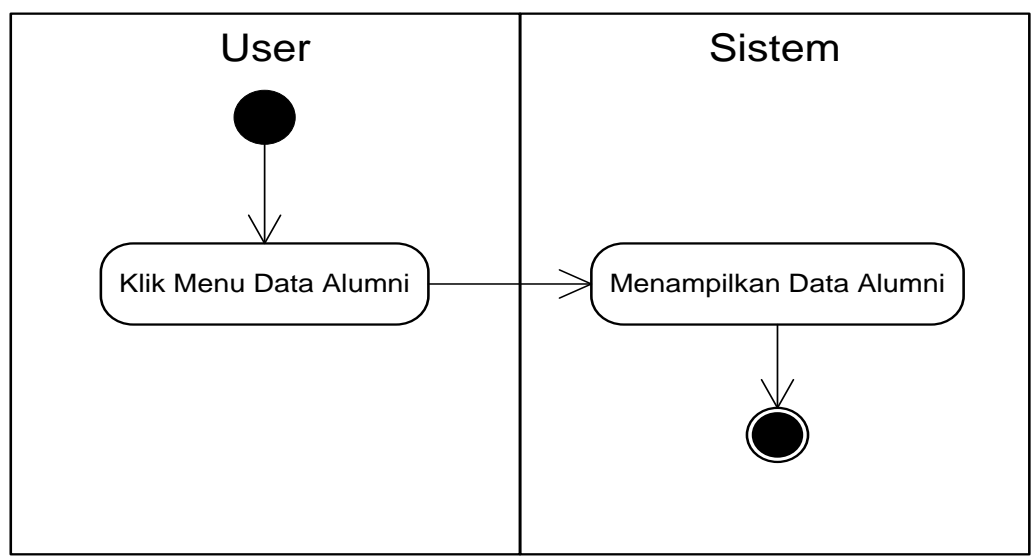

Gambar 3. Activity Diagram Lihat Data Alumni

Activity Diagram pada Gambar 3 memperlihatkan bahwa user dapat melihat data alumni dengan terlebih dahulu mengkllik menu lihat data alumni yang terdapat pada sistem. 


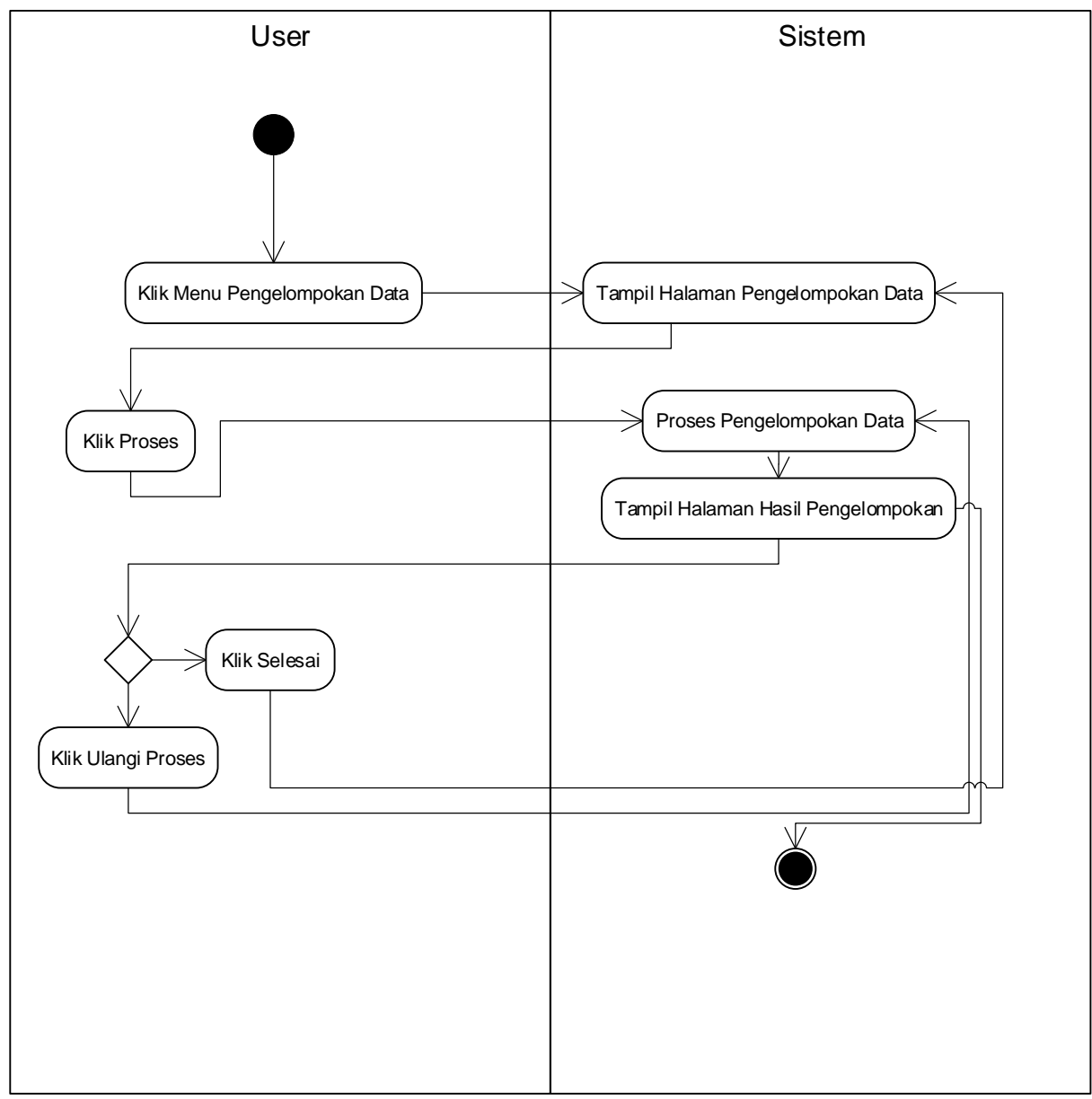

Gambar 4. Activity Diagram Pengelompokan Data Alumni

Actvity Diagram pada Gambar 4 memperlihatkan bahwa user dapat melakukan proses pengelompokan data dimulai saat user meng-klik tombol Proses, maka data yang berupa data alumni UMP akan diproses dan ditentukan pengelompokan dari masingmasing data.

\section{Code}

Tahap ini merupakan tahap implementasi dari tahap design dan penerapan metode K-Means dengan menggunakan bahasa pemrograman PHP. Berikut hasil implementasi menggunakan bahasa pemrograman PHP.

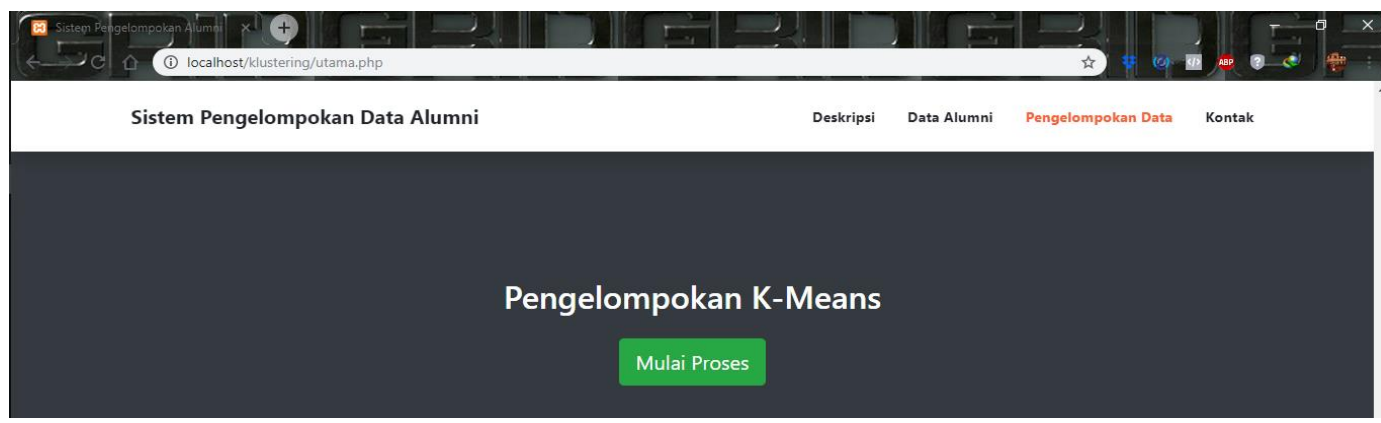

Gambar 5. Halaman Pengelompokan Data

(Metode K-Means untuk Mengelompokkan ........... Ridho Muktiadi, 
Tombol Mulai Proses pada Gambar 5 digunakan untuk mengelompokan data alumni berdasarkan waktu yang digunakan untuk memperoleh pekerjaan pertama. Berikut akan dijelaskan masing-masing tahap dari sistem saat menampilkan dan memproses data.

a. Alokasi Data Secara Acak dan Penentuan Centroid kelompok

Pada Gambar 6 diperlihatkan hasil dari pengalokasian data secara acak ke kelompok yang tersedia. Alokasi ini bersifat acak, jadi semua data dibagi 3 dan masingmasing bagian akan dimasukkan ke tiga kelompok yang sudah dibuat.

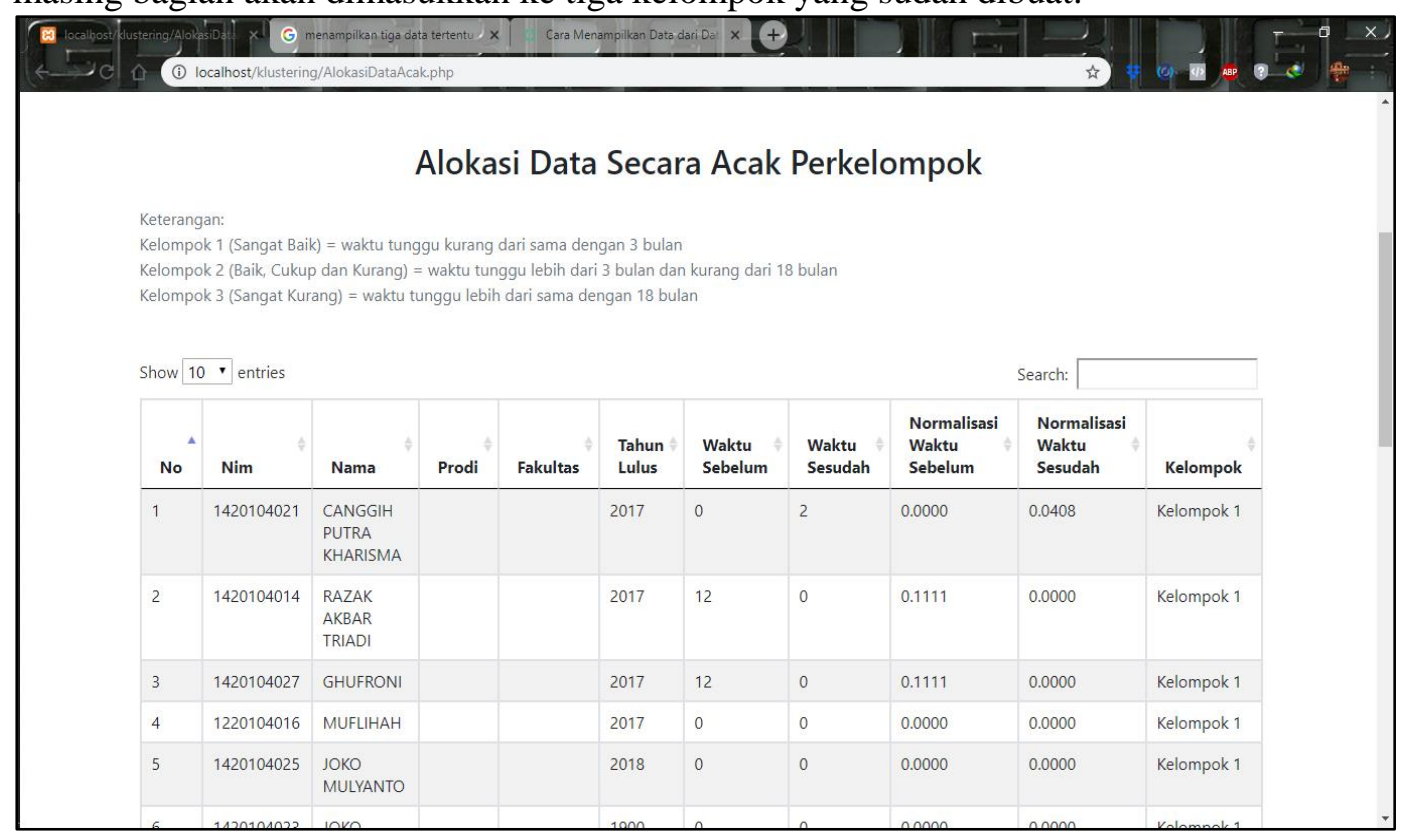

Gambar 6. Alokasi Data Acak Perkelompok

Pada halaman yang sama juga diperlihatkan nilai centroid awal Gambar 7, yang diambil secara acak.

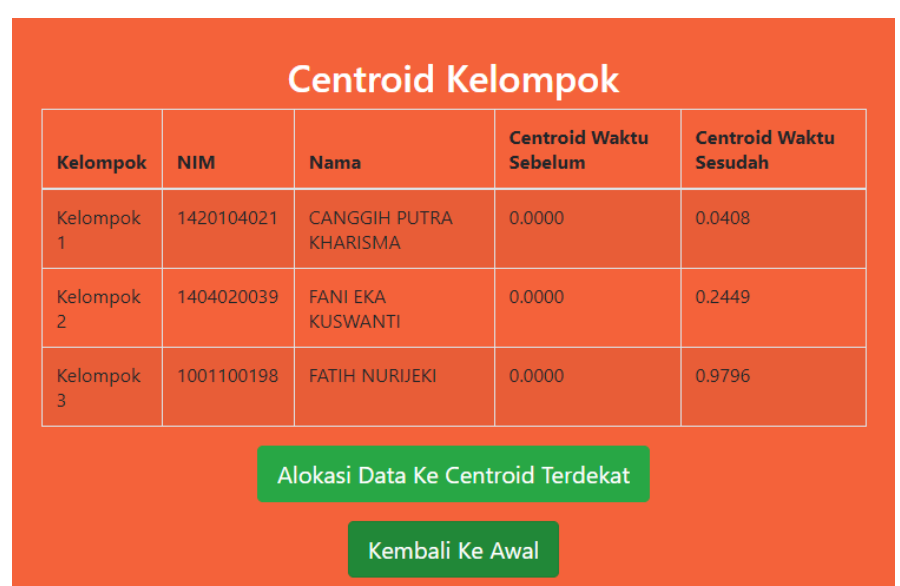

Gambar 7. Alokasi Data Acak Perkelompok

b. Pengelompokan data ke centroid terdekat

Pada tahap ini sistem akan menghitung jarak ke masing-masing centroid. Sistem akan menampilkan semua jarak dari masing-masing centroid kelompok Gambar 8.

(Metode K-Means untuk Mengelompokkan ........... Ridho Muktiadi, 


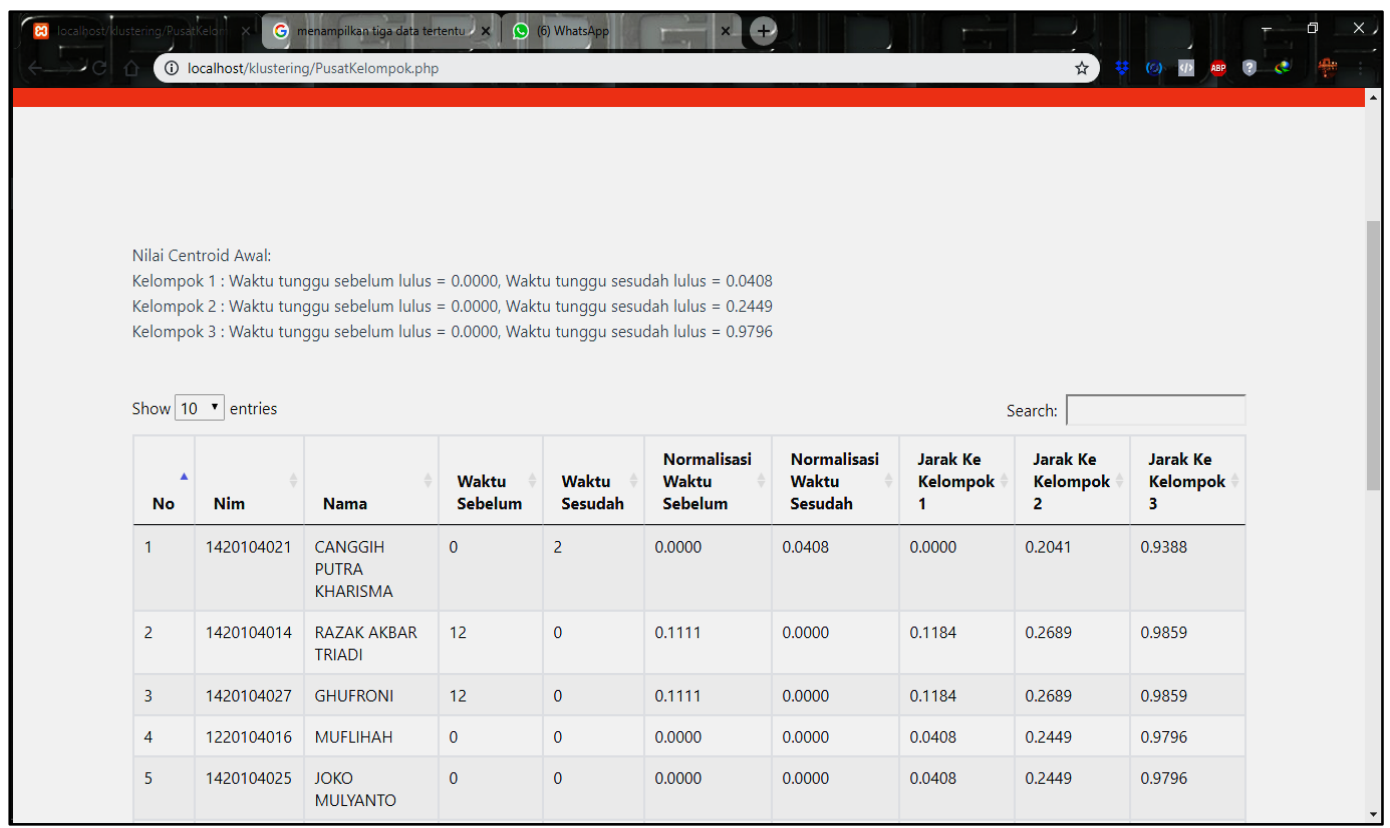

Gambar 8. Penentuan Jarak Kelompok

Setelah jarak masing-masing kelompok ditentukan, selanjutnya sistem akan menampilkan hasil pengelompokan data Gambar 9.

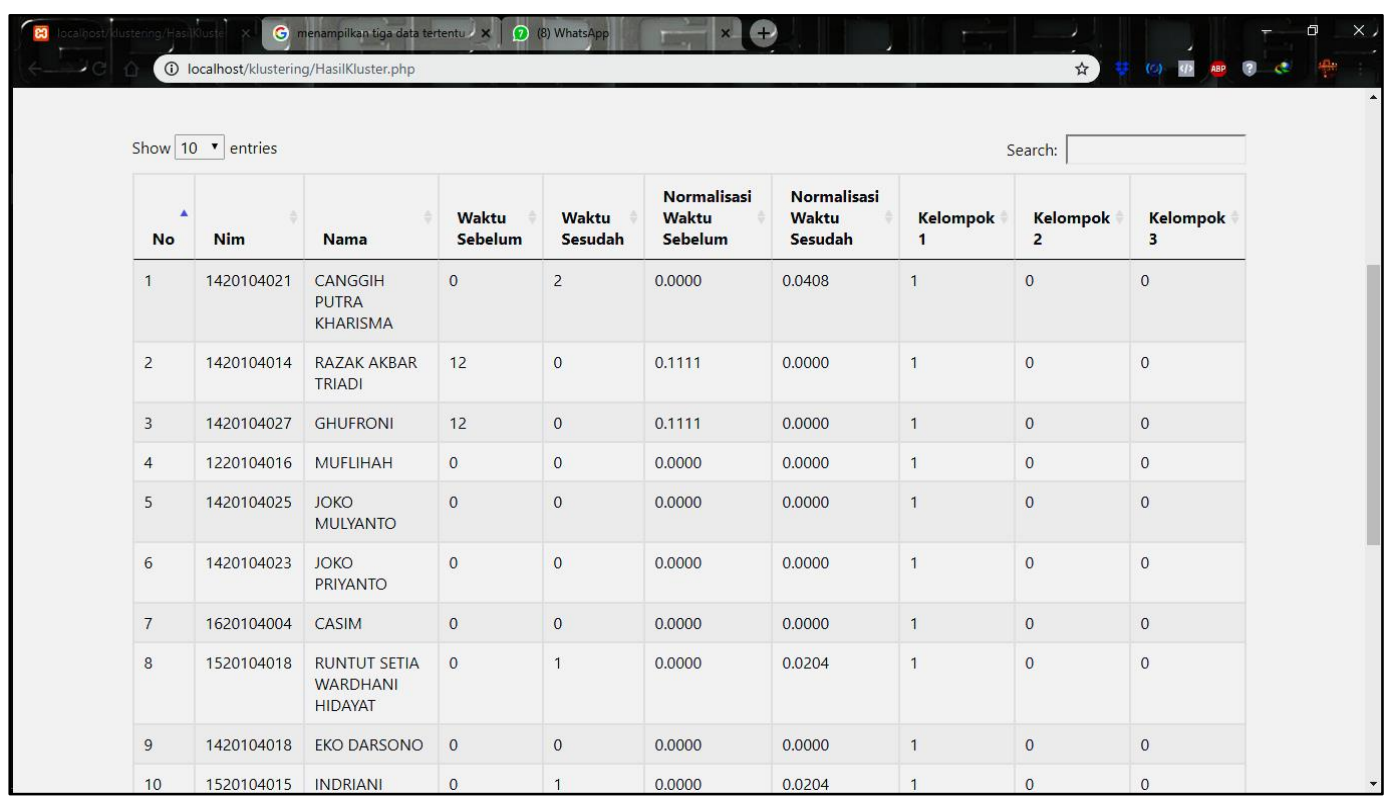

\section{Gambar 9. Hasil Pengelompokkan Data}

Tahap akhir dari pengelompokkan data alumni, sistem akan menampilkan kesimpulan hasil pengelompokkan data dengan disertai keterangan kelompok terbaru beserta keterangan dari kelompok tersebut Gambar 10. 


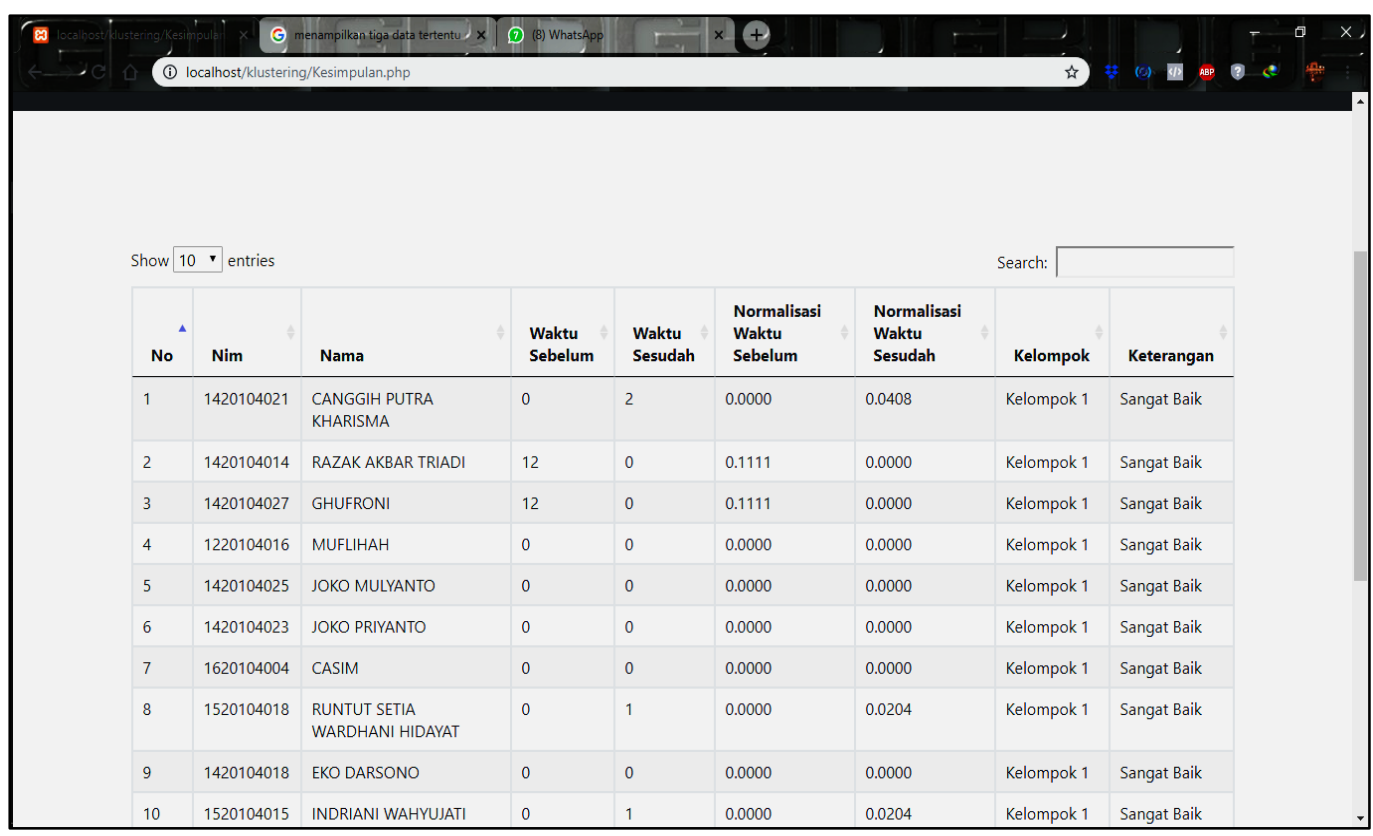

Gambar 10. Hasil Akhir Pengelompokkan Data Tracer Study Berdasarkan Lama Waktu Tunggu

\section{Pengujian}

Tahap terakhir daam penelitian ini adalah melakukan pengujian terhadap system yang sudah dibuat. Pengujian yang dilakukan meliputi:

1. Pengujian Fungsionalitas Sistem

Tabel 1. Pengujian Fungsionalitas Sistem

\begin{tabular}{|c|c|c|c|c|}
\hline No & Komponen & Fungsi & Status & Keterangan \\
\hline 1 & $\begin{array}{l}\text { http://localhost/klusteri } \\
\text { ng/utama.php }\end{array}$ & $\begin{array}{l}\text { Menampilkan halaman awal } \\
\text { sistem }\end{array}$ & Sesuai & - \\
\hline 2 & Menu Navigasi & $\begin{array}{l}\text { Mengarahkan ke tampilan yang } \\
\text { halaman sesuai dengan yang } \\
\text { dipilih }\end{array}$ & Sesuai & - \\
\hline 3 & Tombol Mulai Proses & $\begin{array}{l}\text { Menampilkan Alokasi Data } \\
\text { Secara Acak dan Penentuan } \\
\text { Centroid Perkelompok }\end{array}$ & Sesuai & - \\
\hline 4 & $\begin{array}{l}\text { Tombol Alokasi Data } \\
\text { Ke Centroid Terdekat }\end{array}$ & $\begin{array}{l}\text { Menampilkkan hasil perhitungan } \\
\text { jarak data terhadap masing- } \\
\text { masing centroid kelompok }\end{array}$ & Sesuai & - \\
\hline 5 & $\begin{array}{l}\text { Tombol Kembali Ke } \\
\text { Awal }\end{array}$ & Menampilkan halaman utama & Sesuai & - \\
\hline 6 & $\begin{array}{l}\text { Tombol Hasil } \\
\text { Pengelompokkan }\end{array}$ & $\begin{array}{l}\text { Menampilkan hasil } \\
\text { pengelompokan dengan } \\
\text { menampilkan nilai } 0 \text { atau } 1 \\
\text { perkelompok }\end{array}$ & Sesuai & - \\
\hline 7 & $\begin{array}{l}\text { Tombol Hasil dan } \\
\text { Kesimpulan }\end{array}$ & $\begin{array}{l}\text { Menampilkan hasil } \\
\text { pengelompokkan baru }\end{array}$ & Sesuai & - \\
\hline 8 & Tombol Ulangi Proses & $\begin{array}{l}\text { Menampilkan Alokasi Data } \\
\text { Secara Acak dan Penentuan } \\
\text { Centroid Perkelompok }\end{array}$ & Sesuai & - \\
\hline
\end{tabular}

(Metode K-Means untuk Mengelompokkan .......... Ridho Muktiadi, 
2. Pengujian metode K-Means

Langkah awal dalam pengujian ini adalah menentukan centroid dari masingmasing kelompok. Pusat centroid diambil secara acak yang menjadi perwakilan dari masing-masing kelompok. Hasil dari penentuan centroid dapat dilihat pada Tabel 2.

Tabel 2. Penentuan Centroid Kelompok

\begin{tabular}{cclcc}
\hline Kelompok & NIM & \multicolumn{1}{c}{ Nama } & $\begin{array}{c}\text { Centroid } \\
\text { Waktu Sebelum }\end{array}$ & $\begin{array}{c}\text { Centroid } \\
\text { Waktu } \\
\text { Sesudah }\end{array}$ \\
\hline Kelompok 1 & 1420104021 & CANGGIH PUTRA & 0 & 0.0408 \\
Kelompok 2 & 1404020039 & FHARISMA & 0 & 0.2449 \\
Kelompok 3 & 1001100198 & FATIH NURIJEKI & 0 & 0.9796 \\
\hline
\end{tabular}

Setelah itu, pengujian dilanjutkan dengan menghitung jarak terdekat terhadap centroid menggunakan data: NIM = 1420104014 dan Nama $=$ RAZAK AKBAR TRIADI dengan waktu sebelum $=0.1111$ dan waktu sesudah 0.0000. Data ini digunakan untuk menghitung jarak ke centroid masing-masing kelompok.

- Menghitung jarak ke centroid kelompok 1

$$
\begin{aligned}
& \sqrt{(0,1111-0)^{2}+(0,0000-0,0408)^{2}} \\
& =0.1184
\end{aligned}
$$

- $\quad$ Menghitung jarak ke centroid kelompok 2

$$
\sqrt{(0,1111-0)^{2}+(0,0000-0,2449)^{2}}
$$$$
=0.2689
$$

- $\quad$ Menghitung jarak ke centroid kelompok 3

$\sqrt{(0,1111-0)^{2}+(0,0000-0,9796)^{2}}$ $=0.9859$

Dari perhitungan di atas diperoleh data dengan NIM $=1420104014$ dengan centroid Kelompok 1 diperoleh hasil 0.1184, dengan centroid Kelompok 2 diperoleh hasil 0.2689 dan dengan centroid Kelompok 3 diperoleh hasil 0.9859. Berdasarkan hasil perhitungan di atas dapat disimpulkan bahwa, jarak yang paling dekat adalah centroid Kelompok 1. Sehingga data tersebut dimasukkan ke dalam Kelompok 1.

Berdasarkan hasil di atas dan dibandingkan dengan hasil pengolahan sistem, diperoleh kesamaan. Data dengan NIM $=1420104014$ pada sistem juga berada pada kelompok 1 disertai dengan nilai centroid yang sama (Gambar 11). Sesuai hasil tersebut berarti system sudah sesuai dalam menerapkan metode K-Means dalam mengelompokkan data alumni berdasarkan waktu mencari kerja. 


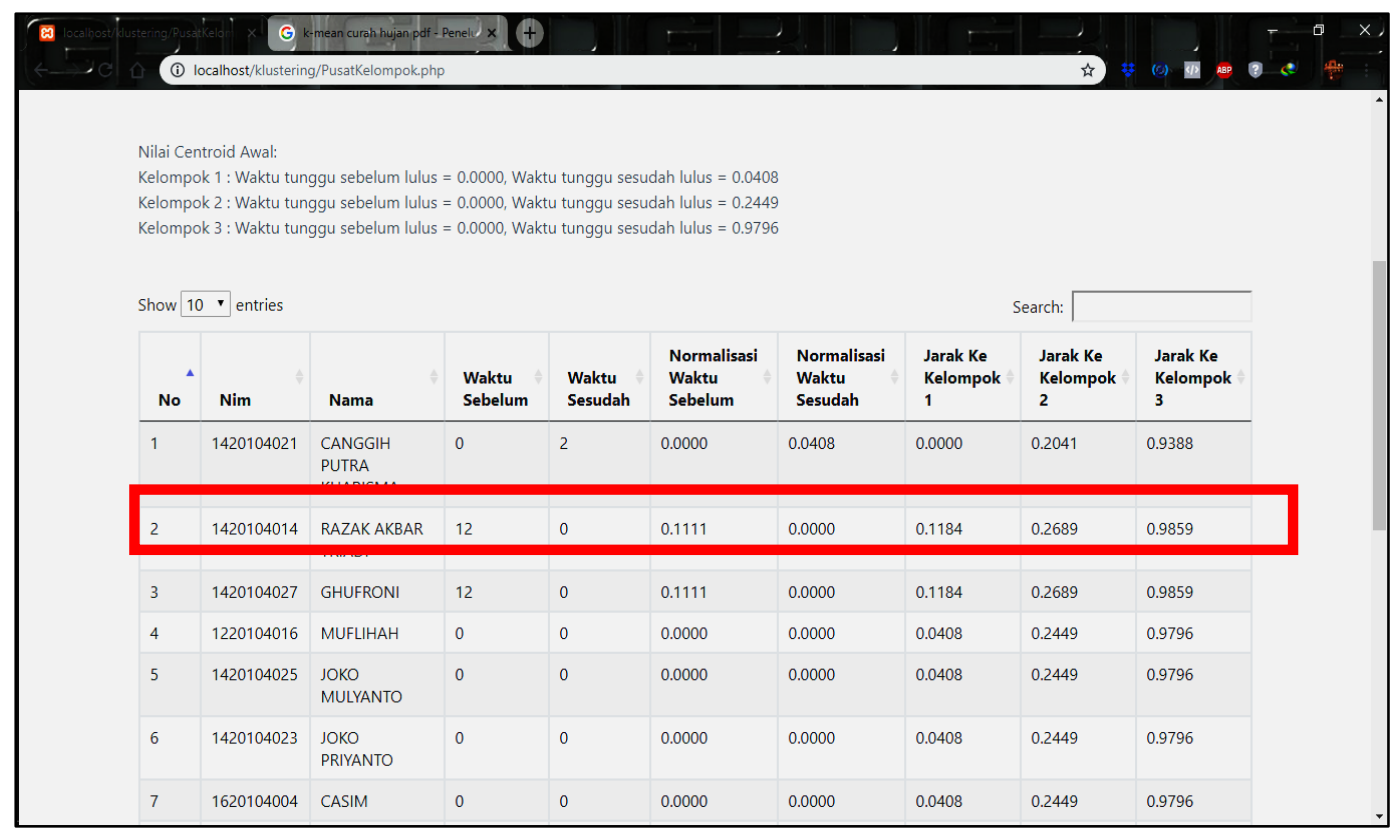

Gambar 11. Perbandingan Hasil Perhitungan Sistem

\section{KESIMPULAN}

Penelitian ini berhasil membangun sebuah sistem untuk dapat mengelompokan data alumni menggunakan metode K-Means berdasarkan waktu alumni mencari pekerjaan. Terdapat 3 kelompok yang digunakan dalam penelitian ini, dan setelah melakukan pengujian, sistem yang dibuat bisa mengelompokkan data alumni yang sudah mengisi tracer study sesuai jarak terdekat dengan centroid masing-masing kelompok.

\section{DAFTAR PUSTAKA}

Badan Akreditasi Nasional Perguruan Tinggi, 2008, Buku VI Matriks Penilaian Instrumen Akreditasi Program Studi Sarjana, Jakarta.

Kemendikbud (Pusat Bahasa), Kamus Besar Bahasa Indonesia, https://kbbi.web.id/alumni.

Muflikhah, L., Ratnawati, D.E., dan Putri, R.R.M. 2018. Buku Ajar Data Mining. UB Press. Malang.

Prasetyo, E., 2012, Data Mining: Konsep dan Aplikasi Menggunakan MATLAB, Andi, Yogyakarta

Pressman, R.S. 2002. Rekayasa Perangkat Lunak: Pendekatan Praktisi (Buku Dua). Andi, Yogyakarta.

Witten, et al., 2012, Data Mining Practical Machine Learning Tools and Technique, 2nd edition, Morgan Kaufmann, San Faransisco. 